\title{
Give Meaning to the Cultural Heritage in its Daily Dimension: Humanize the Space to Favor Social Innovation from the Socioinnovative Dispositions
}

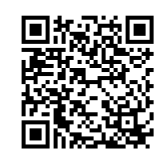

\author{
Maite Jiménez Peralta* \\ Pontifical Catholic University of Valparaíso, Chile
}

Submission: May 21, 2019; Published: May 30, 2019

*Corresponding author: Maite Jiménez Peralta, Pontifical Catholic University of Valparaíso, Waddington 716, Pya. Wide Valparaiso, Chile

\begin{abstract}
Urban development creates spaces in the city that are marginalized. By validating itself as a self-fulfilling prophecy, it generates a social fabric that is invulnerable to social innovation and favorable conditions are established for micro-trafficking and crime to flourish. It is possible to improve the social capital of the members of a community, thanks to the integration of the community around the traditional values that sustain it. The tourism industry offers itself as an interesting prospect, since the opportunity to rescue the forgotten history of these places has proven to be an engine of development in different parts of the planet, articulating a network of possibilities as it returns these places to the map, making them visible and pressing for local governments to derive resources from it. The patrimony thus becomes a double-edged sword, because that which rescues history also loses it for the inhabitants themselves. Reversing these processes means reconnecting the subject with its territory and allowing that from the sharing of their interests on the place, they can organize a social substrate able to manage the opportunities and the resolution of their social problems. Thus activating a social innovation from the socio-innovative dispositions of its inhabitant, requires humanizing the sense of space and how a given community is capable of sustaining an urban identity. For there to be a sustainable cultural heritage, it is necessary for the resident community to be able to actively link with it, because not to do so is to make it a sterile, artificial and packaged object for a tourist, but lacking an identity
\end{abstract}

Keywords: Social innovation; Rehumanization; Heritage; Public space; Tourism

\section{Introduction}

Urban development creates spaces in the city that are marginalized [1], where the inhabitants build a story, which in its continuous mention of precariousness, give priority to a narrative of failures that finally configures conditions to justify the abandonment of the territory. The other (the neighbor) is seen as a threatening subject and the families reduce their participation in spaces of community interaction, further weakening social structures. It is possible to improve the social capital of the members of a community, understood as the set of resources rooted within their network of social relationships, plus all the resources accessible through that same network [2], thanks to the integration of the community around the traditional values that sustain it. For this to happen, it is necessary to understand space as a text from which each subject is constituted in relation to another [3]. Being a community becomes an exercise in alterity and it is in the repetition of their story that each subject becomes part of a community [4]. In addition, from the performative power that it offers, it allows to find transformation possibilities for the subject and for the territory. A new story, in dialogue with another and with its history, is creating an affective ecology that positions the interlocutors from new possibilities [5].

\section{Heritage as a Frozen Story}

In these areas, the challenge of generating better economic opportunities for its inhabitants, is of interest to the authorities and the tourism industry is offered as an interesting perspective, since the opportunity to rescue the forgotten history of these places has proven to be an engine of development in different parts of the planet. Cultural, patrimonial or community tourism allows forgotten places to be placed on the map [6]. To this increase of tourists, there is associated a revitalization of the places generating a creative economy [7]. The tourist is an avid buyer for new products in different formats: walks, lodging, experiences, memories, food, etc. Rescuing this heritage, whether in its buildings as material heritage or in its traditions as intangible heritage, is articulating a network of possibilities 
for a place, as it returns them to the map, making them visible and pressing for local governments to derive resources from it. Heritage thus becomes a double-edged sword, as that which rescues history, and place, freezing both at a point of time. In addition to being put in common and at the service of tourism, as is the case of a world heritage site, it is lost for the inhabitants, who are questioned by the tourists themselves to remain faithful to it [8].

\section{The dilemma for the use of Space}

The space in spite of being common stops being public, since its use on the part of the community that inhabits it is restricted and regulated by the requirements of the patrimony. Real estate speculation and policies to safeguard heritage, bring the phenomenon of gentrification hand in hand, leaving the neighbor without the possibility of intervening in their daily spaces. The social space constructed in function of an economic capital and a cultural capital, is excluding the own neighbors who are marginalized in the negotiation of the interests on the territory. To integrate them, they must have access to both types of capital and the mechanism is social innovation. This to be effective in these places, should be understood as a process and not as a result, and means anchoring urban development with a more social sense and inspired by community policies [9]. From the urban space, the community needs to create and find common places to socialize, from the meaning that each subject contributes to that cultural construction [10]. In this way, a shared identity allows affectively linking the subjects with their territory [11] and not only from the assignment of a patrimonial category. The neighbor is perceived to be subject from a history to a particular community integrating it towards an urban social identity, which expresses the relationship between the environmental past, the socially elaborated meanings related to space, and the particular way in which the subject has integrated them, cognitive and affectively, in the way in which it establishes its links $[12,13]$.

\section{The Socio-Innovative Dispositions}

For this reason, it is not possible to think about economic growth from heritage tourism, without thinking about the human as an essential capital $[14,15]$. Only with the active participation of community actors, it becomes possible to reconsider critical social problems as opportunities [16]. The dilemma lies in how to reconcile the need for a social innovation that allows a place to be economically stimulated and at the same time maintain this state of immobility of its heritage. If we add to this a scenario where precariousness and marginalization have broken their community ties, conditions favor more a gentrification than an improvement in the quality of life of its inhabitants. Examples of the latter are in various parts of the globe, such as Chueca in Madrid, Malmö in Switzerland or San Telmo in Argentina. The arrival of groups with better income, hand in hand with real estate speculation are evicting the original inhabitants. When this occurs in sectors where citizen participation has been systematically invalidated, the restriction on access to what they consider their own territory predisposes to abandonment, whether in a physical (emigration) or emotional (detachment) sense. There is a "gentrification without expulsion" [1]. It often happens that these spaces, in their dimension of heritage tourism, end up being a theatrical scenario of a frozen history splitting from the daily life of its inhabitants $[17,18]$ and these distancing themselves from citizen participation.

For this reason, reconnecting the territory, especially with public space, is also a way to recreate the social fabric that sustains a place. It is in its public nature where neighbors can share and generate strategies to become part of the neighborhoods and establish community alliance networks [19].Working towards social innovation is also working on patterns of social behavior, routines, practices and values that are socially accepted and widely spread throughout the community. It requires recognizing an "other" as also an inhabitant of the neighborhood and as such, recreating the history of a place to conform a cultural identity [20]. The substrate for this is to explore the socio-innovative conditions remaining in a community that has often lost hope and where the neighbor is seen as threatening. These are interpreted as "dispositions or potentialities of the subjects in their interpersonal relationships that, together with the possibilities that the community itself and the place they inhabit, allow generating attitudes and transforming and sustainable actions, in order to empower the participants of a community. These conditions, understood in a framework of eco-development, are the foundation to build contexts of relevance that generate sustainable community projects aimed at the quality of intra and inter-family life" [21,22].

\section{Conclusion}

The identification of patrimonial spaces has been seen as an interesting resource to reactivate disadvantaged areas. Many times, this process, far from bringing wealth to its inhabitants, evicts them, allowing the arrival of new residents. In Latin America, this eviction has not always been physical, but often the effect is that the original residents are relegated in access to public spaces, which are occupied by tourists who create an itinerant population in the place or new residents, promoters of tourism-oriented businesses (restaurants, tourism agencies, accommodation, etc.). San Pedro de Atacama in Chile is an example of this. Thus the promise of an improvement in the quality of life is being diluted because the different interests on the territory are being negotiated by different agents than the natural residents. These, in turn, are marginalized from citizen participation, perceiving themselves as alien to their neighborhoods, streets and squares isolating themselves.

Reversing these processes means reconnecting the subject with its territory and allowing that from the sharing of their interests on the place, they can organize a social substrate able to manage the opportunities and the resolution of their social problems. Thus activating a social innovation from the socio- 
innovative dispositions of its inhabitant, requires humanizing the sense of space and how a given community is capable of sustaining an urban identity. For there to be a sustainable cultural heritage, it is necessary that the resident community can actively link with this because not to do so, is to make it a sterile, artificial and packaged object for a tourist, but lacking an identity.

\section{Acknowledgements}

I want to express my acknowledgements to my colleagues Dr. Gladys Jiménez, Dr. Gonzalo Bravo and MSc Jacqueline Reveco, who have worked in the La Matriz neighborhood.

\section{References}

1. Frediani J, Rodríguez-Tarduci R, Cortizo D (2016) Proceso de Gentrificación en Áreas Periféricas del Partido de La Plata. Argentina Quid 16(9): 9-37.

2. Nahapiet J, Ghoshal S (1998) Social Capital, Intellectual Capital, and the Organizational Advantage. The Academy of Management Review 23(2): 242-266.

3. Augé M (1996) El sentido de los otros. Actualidad de la antropología. Paidós, Madrid, Spain.

4. Nancy J (2008) The being-with of being-there. Continental Philosophy Review 41(1): 1-15.

5. Simpson P (2015) What remains of the intersubjective? On the presencing of self and other. Emotion, Space and Society, 14(1): 65-73.

6. González Damián A (2004) El anfitrión como actor social en el turismo. Reflexiones desde el caso de Ixtapan de la Sal, México. Revista de Ciencias Sociales (Cr) 3(105): 155-168.

7. Coy P (2000) The creative economy: Which companies will thrive in the coming years? Those that value ideas above all else. Business Week Online.

8. Delgadillo V (2014) La política del espacio público y del patrimonio urbano en la ciudad de México. Discurso progresista, negocios inmobiliarios y buen comportamiento social. XIII Coloquio Internacional de Geocrítica El control del espacio y los espacios de control Barcelona, p. 5-10.
9. Moulaert F, Martinelli F, González S (2007) Social Innovation in Governance in European Cities: Urban Developments between Path Dependency and Radical Innovation. European Urban and Regional Studies 14(3): 195-209.

10. Lindón A (2007) Los imaginarios urbanos y el constructivismo geográfico: los hologramas espaciales. EURE 33(99): 31-46.

11. Holton M (2017) A place for sharing: The emotional geographies of peer-sharing in UK University halls of residences. Emotion, Space and Society 22: 4-12.

12. Valera S, Pol E (1994) El concepto de identidad social urbana: una aproximación entre la Psicología Social y la Psicología Ambiental. Anuario de Psicología 1(62): 5-24.

13. Valera S (2014) A study of the relationship between symbolic urban space and social identity processes. Revista de Psicología Social 12(1): 17-30.

14. Bucci A, Segre G (2011) Culture and human capital in a two-sector endogenous growth model. Research in economics 65(4): 270-293.

15. Radovic D (2016) Measuring the non-measurable: On mapping subjectivities in Urban research. City, culture \& society 7: 17-24.

16. Lisetchi M, Brancu L (2014) The Entrepreneurship Concept as a Subject of Social Innovation. Procedia - Social and Behavioral Sciences, 124(20): 87-92.

17. Cocola-Gant A (2016) Holiday rentals: the new gentrification battlefront. Sociological Research Online, 21(3): 10.

18. Hiernaux D, González C (2014) Turismo y gentrificación: pistas teóricas sobre una articulación. Revista de Geografía Norte Grande, 58(1): 55-70.

19. Okano H (2016) Cultural editing for creativity: A framework from society persons/thing, event, road, and memories. City, cultural \& society 7(2016): 55-61.

20. Certeau M (2007) Historia y psicoanálisis. Universidad Iberoamericana, México.

21. Jiménez M, Jiménez G, Bravo G, Reveco J (2018) Disposiciones socioinnovativas para el desarrollo local; sueños para el barrio La Matriz. Revista El Topo 9(2): 39-62.

22. Thomasz A (2016) Los nuevos distritos creativos de la ciudad de Buenos Aires: la conversión del barrio de La Boca en el Distrito de las Artes. Eure 42(126): 123-144.

\section{Your next submission with Juniper Publishers will reach you the below assets}

- Quality Editorial service

- Swift Peer Review

- Reprints availability

- E-prints Service

- Manuscript Podcast for convenient understanding

- Global attainment for your research

- Manuscript accessibility in different formats

( Pdf, E-pub, Full Text, Audio)

- Unceasing customer service

Track the below URL for one-step submission

https://juniperpublishers.com/online-submission.php 